\title{
Food Security in Households of People Living With Human Immunodeficiency Virus/Acquired Immunodeficiency Syndrome: A Cross-sectional Study in a Subdivision of Darjeeling District, West Bengal
}

\author{
Pallabi Dasgupta', Sharmistha Bhattacherjee', Dilip Kumar Das² \\ ${ }^{1}$ Department of Community Medicine, North Bengal Medical College \& Hospital, Siliguri; ${ }^{2}$ Department of Community Medicine, Burdwan Medical \\ College \& Hospital, Bardhaman, India
}

Objectives: Human immunodeficiency virus (HIV)/acquired immunodeficiency syndrome (AIDS) adversely impacts food security in households of people living with HIV/AIDS (PLWHA). Little research has focused on food insecurity among PLWHA in India. The purpose of this study was to identify the prevalence of and factors relating to food security in households of PLWHA in the Siliguri subdivision of Darjeeling, West Bengal, India.

Methods: A cross-sectional community-based study was carried out among 173 PLWHA residing in Siliguri and registered at the Antiretroviral Therapy Centre of North Bengal Medical College \& Hospital. Data was collected at the household level with interviews of PLWHA using a food security survey instrument. We analyzed the associations using logistic regression.

Results: The prevalence of household food security among the participants was $50.9 \%$ (88/173). Five years or more of schooling, higher socioeconomic class and males were found to be significantly associated with a higher likelihood of food security. A later stage of the disease and the presence of other family members with HIV/AIDS were significantly associated with a lower likelihood of food security. The major coping strategies to deal with food insecurity in the acute phase HIV infection included borrowing money (56.1\%), followed by spousal support, loans from microfinance institutions, banks, or money lenders, borrowing food, or selling agricultural products.

Conclusions: The present study revealed that only about half of households with PLWHA were food secure. Prior interventions relating to periods of food and economic crisis as well as strategies for sustaining food security and economic status are needed in this area.

Key words: Human immunodeficiency virus, Food security, Households, India

\section{INTRODUCTION}

Received: February 24, 2016 Accepted: July 19, 2016

Corresponding author: Pallabi Dasgupta, MBBS

Siliguri 734012, West Bengal, India

Tel: +91-8296745820, Fax: +91-3532545478

E-mail: dasguptapallabi@yahoo.in

This is an Open Access article distributed under the terms of the Creative Commons Attribution Non-Commercial License (http://creativecommons.org/licenses/by$\mathrm{nc} / 4.0 /$ ) which permits unrestricted non-commercial use, distribution, and reproduction in any medium, provided the original work is properly cited.
The World Food Summit in 1996 defined food security as the status where "all people at all times have access to sufficient, safe, nutritious food to maintain a healthy and active life" [1]. Food security is built on the three pillars of food availability, access, and utilisation. Whether households receive enough food, its distribution within the household, and whether that food fulfils the nutritional needs of all household members are factors of food security clearly linked to health [1]. 
With rising infection rates [2], particularly in resource-poor countries, the pandemic of human immunodeficiency virus (HIV)/acquired immunodeficiency syndrome (AIDS) has started to have a significant impact on food security and nutrition, which may create a deadly cycle of illness and nutritional deprivation [3]. HIV/AIDS typically strikes people between 15 and 50 years old-the bulk of the labour force [4]. It undermines the ability of individuals and households to feed and care for themselves, leading to food insecurity. This, again, leads to malnutrition, which can aggravate HIV and accelerate the development of AIDS. The households of people living with HIV/AIDS (PLWHA) are thus highly vulnerable with regard to food and livelihood insecurities.

Exploring this aspect of HIV/AIDS will help policy makers to undertake appropriate measures to deal with food insecurity in the households of PLWHA. These measures are necessary in tune with Goal 1 and Goal 6 of the United Nations Millennium Development Goals, that is, to eradicate extreme poverty and hunger and to combat HIV/AIDS.

Issues of household food security and HIV/AIDS have been dealt with in various studies conducted in sub-Saharan African countries like Swaziland [5], Uganda [6], and Ethiopia [7]. Few published studies have addressed the Indian context [8,9].

The National AIDS Control Organisation under Government of India has classified districts in India into A, B, C, and D categories, based on HIV burden [10]. Category A and $B$ districts are high-prevalence districts prioritised for program interventions. Category A includes districts with HIV prevalence $>1 \%$ among antenatal clinic (ANC) attendees. Category B includes districts with HIV prevalence $<1 \%$ among ANC attendees, but prevalence $>5 \%$ in any high-risk group such as female sex-workers, injection drug users, or others. Although the Darjeeling district of West Bengal belongs to category $B$ with respect to HIV/AIDS prevalence [10], published studies are lacking here.

In consideration of these aspects, a community-based study was done to find out the prevalence of and factors relating to food security in the households of PLWHA in the Siliguri subdivision of Darjeeling, West Bengal.

\section{METHODS}

\section{Study Participants}

A community-based cross-sectional study was conducted from May to October 2015 in Siliguri, a subdivision of Darjeeling district in the state of West Bengal, India. Siliguri consists of the 33 wards of the Siliguri Municipal Corporation and four community-development blocks [11]. North Bengal Medical College \& Hospital (NBMCH) possesses the only anti-retroviral therapy (ART) centre in Siliguri, which caters to patients from the entire Darjeeling district as well as from the neighbouring districts of Jalpaiguri, Uttar and Dakshin Dinajpur, the states of Bihar and Assam, and the neighbouring country of Nepal.

From among all PLWHA registered at the ART Centre of NBMCH during a reference time frame of July 2009 to June 2014, the primary participants consisted of those residing in Siliguri, aged 18 years to 64 years, currently on ART. The households of these primary participants were the study units for the assessment of food security.

Owing to a scarcity of community-based studies examining food security among PLWHA, a pilot study was conducted with a convenience sample of 30 patients attending clinics of medicine department of NBMCH where the prevalence of food secure households was measured as $50 \%$. Hence, anticipating a proportion of food secure households among PLHWA at $50 \%$, with a $95 \%$ confidence interval $(\mathrm{Cl}), 15 \%$ relative precision, and an additional $10 \%$ either for non-response or for multiple patients in the same household, the sample size was calculated to be 188 [12].

From the list of eligible primary participants registered at the ART Centre in the reference time frame of five years (prepared beforehand), 188 participants were selected by a simple random sampling technique using a computer-generated random number table. In case of multiple PLHWA in a single household, only one was interviewed from each household.

\section{Measurements}

The interview schedule consisted of background characteristics, disease-related history, and a validated version of the Food Security Survey (FSS) instrument [13]. Any available medical records or prescriptions from the ART Centre were also reviewed for relevant data.

Background characteristics included age (in completed years, as recorded in medical records), religion (Hindu or other), sex, education ( $<5$ years or $\geq 5$ years of schooling), marital status, type of family, socioeconomic status (SES) using a modified BG Prasad scale $[14,15]$ and total-to-earning-member ratio (the ratio of total family members to the number of earning members in the family). The BG Prasad classification $[14,15]$ was used to measure the SES of individuals, as well as families, using monthly per capita income $(\mathrm{PCl})$, which is ap- 
plicable to both urban and rural areas.

Disease-related variables included the duration of disease, the stage of the disease based on World Health Organization (WHO) clinical staging [16] (initial and current), and the presence of other family member with HIV/AIDS. The initial stage of the disease refers to the stage at which participants initially presented at the time of their registration at the ART Centre. The current stage of the disease refers to the stage of the disease as recorded at the time of the participant's last visit to the ART Centre.

The WHO clinical staging of HIV in adults and adolescents [16] — based on specific clinical findings and symptoms categorised on a progressive scale from one to four, which guides the diagnosis, evaluation, and management of HIV/AIDS-is used in India. It was developed for resource-constrained settings and does not require a CD4 count.

The FSS is a 17-question survey instrument (nine basic and eight sub-questions) that measures household "access" to food through available resources to purchase or barter. Originally designed by the US Department of Agriculture, the FSS has been field tested in various countries, including India [13].

There are two methods for scoring the FSS. The first method measures the occurrence or prevalence of food security. Nine basic questions that compose the scale measure the prevalence of food security or insecurity (considered the prevalence [P] score). The responses are recorded as 'yes' or 'no'. The coded responses ('yes' $=1,{ }^{\prime} n o^{\prime}=0$ ) are summed to give a raw score (between 0 and 9 ).

The second method measures how severe or chronic the client's level of food insecurity is (the chronic [C] score). If the response to any of the main nine questions is 'yes', corresponding sub-questions (one for each main question, with the exception of question eight) ask how often a phenomenon occurred ('rarely', 'sometimes', or 'often'). The answers "yes, frequently" or "yes, sometimes" receive a score of one, and the answer of "yes, rarely" receives a score of zero. Again, the points are summed to give a raw $\mathrm{C}$ score, upon which basis the client is classified as either food secure or food insecure. Households that score 0-2 are considered food secure and those that score 3-9 are considered food insecure by both scoring methods.

The schedule also included open-ended questions about participants' coping strategies during financial stress in the acute phase of the disease. The responses were grouped into discrete non-overlapping categories. Multiple responses were invited.

After obtaining ethical clearance from the institutional ethics committee and permission from the State AIDS Prevention and Control Society, concerned authorities at the district level and the ART Centre were informed of the study. The contact details of selected participants were obtained beforehand from the ART Centre and with the help of two non-governmental organisations (NGOs) working for PLWHA: Ekta-Vihaan and Sanghabaddho. Households were visited at a mutually convenient time after telephone conversations with the participants. Participants were interviewed, maintaining the confidentiality and anonymity of the information, after obtaining informed consent.

\section{Statistical Analysis}

Binary logistic regression was used for the analysis. The $\mathrm{P}$ score and $\mathrm{C}$ score, representing the food security status of a household, were the dependent variables, dichotomous in nature, where 'food secure' $=1$; 'food insecure' $=0$. Households with scores 0-2 were categorised as food secure and 3-9 as food insecure using the FSS.

The adjusted odds ratio (AOR) for household food security was calculated after adjusting for background predictor variables (age, religion, sex, education, current marital status, type of family, SES, total-to-earning-member ratio) and after adjusting for disease-related predictor variables (duration of disease, initial and current stage of disease, and presence of other family members with HIV/AIDS). The analysis was performed with IBM SPSS version 20.0 (IBM Corp., Armonk, NY, USA). A pvalue $<0.05$ was considered significant.

\section{RESULTS}

Out of 533 eligible primary participants, the households of 188 PLWHA were approached. However, only 173 could be successfully interviewed. Four of these households were repeated samples, that is, they had already been approached for other selected PLWHA, and 11 eligible participants refused to respond (response rate, 92\%).

The mean age of participants was $36.6 \pm 9.2$ years (range, 20 to 56) with 96 males (55.5\%), 149 Hindus (86.1\%), and 118 currently married $(68.2 \%)$. Participants with $\geq 5$ years of schooling numbered 111 (64.2\%), with 90 (52.0\%) from nuclear families, 106 (61.3\%) belonging to lower SES (monthly PCI $<3070$ Indian rupees) and 118 (68.2\%) having a total-to-earn- 
Table 1. Association of background variables with food security

\begin{tabular}{|c|c|c|c|c|}
\hline Variables & $\begin{array}{l}\text { Food } \\
\text { secure }\end{array}$ & $\begin{array}{c}\text { Food } \\
\text { insecure }\end{array}$ & $\begin{array}{c}\text { Total } \\
(n=173)\end{array}$ & $\begin{array}{c}\text { AOR }^{1} \\
(95 \% \mathrm{CI})\end{array}$ \\
\hline \multicolumn{5}{|l|}{ Age (y) } \\
\hline$<40$ & $54(47.4)$ & $60(52.6)$ & $114(65.9)$ & 1.00 (reference) \\
\hline$\geq 40$ & $34(57.6)$ & $25(42.4)$ & $59(34.1)$ & $1.67(0.74,3.77)$ \\
\hline \multicolumn{5}{|l|}{ Religion } \\
\hline Hindu & $79(53.0)$ & $70(47.0)$ & $149(86.1)$ & 1.00 (reference) \\
\hline Others ${ }^{2}$ & $9(37.5)$ & $15(62.5)$ & $24(13.9)$ & $0.48(0.15,1.49)$ \\
\hline \multicolumn{5}{|l|}{ Sex } \\
\hline Male & $58(60.4)$ & $36(39.6)$ & $96(55.5)$ & 1.00 (reference) \\
\hline Female & $30(39.0)$ & $47(61.0)$ & $77(44.5)$ & $0.39(0.18,0.82)^{*}$ \\
\hline \multicolumn{5}{|l|}{ Marital status } \\
\hline Currently married & $64(45.8)$ & $54(54.2)$ & $118(68.2)$ & 1.00 (reference) \\
\hline Others ${ }^{3}$ & $24(43.6)$ & $31(56.4)$ & $55(31.8)$ & $0.87(0.39,1.95)$ \\
\hline \multicolumn{5}{|l|}{ Type of family } \\
\hline Nuclear & $45(50)$ & $45(50)$ & $90(52.0)$ & 1.00 (reference) \\
\hline Joint & $43(51.8)$ & $40(48.2)$ & $83(48.0)$ & $1.27(0.61,2.66)$ \\
\hline \multicolumn{5}{|l|}{ Education (y) } \\
\hline$<5$ & 20 (32.3) & $42(67.7)$ & $62(35.8)$ & 1.00 (reference) \\
\hline$\geq 5$ & $68(61.3)$ & $43(38.7)$ & $111(64.2)$ & $2.67(1.20,5.95)^{*}$ \\
\hline \multicolumn{5}{|c|}{ Socioeconomic status } \\
\hline $\begin{array}{l}\text { Class I and II (PCI } \\
\quad \geq \text { INR 3070/mo) }\end{array}$ & $52(77.6)$ & $15(22.4)$ & $67(38.7)$ & 1.00 (reference) \\
\hline $\begin{array}{l}\text { Class III, IV, and V } \\
\text { (PCI < INR } \\
3070 / \mathrm{mo})\end{array}$ & $36(34.0)$ & $70(66.0)$ & $106(61.3)$ & $0.13(0.05,0.29)^{*}$ \\
\hline \multicolumn{5}{|c|}{ Total-to-earning-member ratio } \\
\hline$<4$ & $63(53.4)$ & $55(46.6)$ & $118(68.2)$ & 1.00 (reference) \\
\hline$\geq 4$ & $25(45.5)$ & $30(54.5)$ & 55 (31.8) & $1.86(0.81,4.27)$ \\
\hline Total & $88(50.9)$ & $85(49.1)$ & $173(100)$ & \\
\hline
\end{tabular}

Values are presented as frequency (\%).

$\mathrm{AOR}$, adjusted odds ratio; $\mathrm{Cl}$, confidence interval; $\mathrm{PCl}$, per capita income; INR, Indian rupees; Class I, $\geq$ INR 6140; Class II, INR 3070-6139; Class III, INR 1842-3069; Class IV, INR 921-1841; Class V, $\leq$ INR 920.

${ }^{1} \mathrm{AOR}$ was determined using binary logistic regression. For each independent variable, the AOR was calculated after adjusting for other independent variables.

${ }^{2}$ Other religions like Muslim, Christian, etc.

${ }^{3}$ Other marital status implies unmarried/divorced/separated.

${ }^{*} p<0.05$.

ing-member ratio $<4$ (Table 1$)$.

Out of the participants, 110 (63.6\%) had a disease duration of $\geq 2$ years, 114 (65.9\%) had other family members with HIV/ AIDS, and 156 (90.2\%) currently have an earlier stage of the disease (stage 1 or 2) (Table 2).

Food security was prevalent among 88 (50.9\%) households; 85 (49.1\%) were food insecure (based on P score; Table 1); 75 (43.4\%) were chronically food insecure (Table 3 ).
Table 2. Association of disease-related variables with food security

\begin{tabular}{|c|c|c|c|c|}
\hline Variables & $\begin{array}{l}\text { Food } \\
\text { secure }\end{array}$ & $\begin{array}{c}\text { Food } \\
\text { insecure }\end{array}$ & $\begin{array}{c}\text { Total } \\
(n=173)\end{array}$ & $\begin{array}{c}\text { AOR }^{1} \\
(95 \% \mathrm{CI})\end{array}$ \\
\hline \multicolumn{5}{|c|}{ Duration of disease (y) } \\
\hline$\geq 2$ & $54(49.1)$ & $56(50.9)$ & $110(63.6)$ & 1.00 (reference) \\
\hline$<2$ & $34(54.0)$ & $29(46.0)$ & $63(36.4)$ & $1.53(0.78,3.01)$ \\
\hline \multicolumn{5}{|c|}{ Initial stage of disease ${ }^{2}$} \\
\hline Stage 3 and 4 & $28(50.9)$ & $27(49.1)$ & 55 (31.8) & 1.00 (reference) \\
\hline Stage 1 and 2 & $60(50.8)$ & $58(49.2)$ & $118(68.2)$ & $0.88(0.44,1.76)$ \\
\hline \multicolumn{5}{|c|}{ Current stage of disease ${ }^{3}$} \\
\hline Stage 3 and 4 & $5(29.4)$ & $12(70.6)$ & $17(9.8)$ & 1.00 (reference) \\
\hline Stage 1 and 2 & $83(53.2)$ & $73(46.8)$ & $156(90.2)$ & $4.90(1.43,16.80)^{*}$ \\
\hline \multicolumn{5}{|c|}{ Presence of other family members suffering from HIV/AIDS } \\
\hline Yes & $52(45.6)$ & $62(54.4)$ & $114(65.9)$ & 1.00 (reference) \\
\hline No & $36(61.0)$ & $23(39.0)$ & $59(34.1)$ & $2.24(1.13,4.45)^{*}$ \\
\hline Total & $88(50.9)$ & $85(49.1)$ & $173(100)$ & \\
\hline
\end{tabular}

Values are presented as frequency (\%).

AOR, adjusted odds ratio; $\mathrm{Cl}$, confidence interval; $\mathrm{ART}$, anti-retroviral therapy; WHO, World Health Organization; HIV, human immunodeficiency virus; AIDS, acquired immunodeficiency syndrome.

${ }^{1} \mathrm{AOR}$ was determined using binary logistic regression. For each independent variable, the AOR was calculated after adjusting for other independent variables.

'Initial stage of the disease at the time of registration at the ART Centre based on WHO clinical staging of HIV disease in adults and adolescents.

${ }^{3}$ Stage of disease as recorded at the time of patient's last visit to ART Centre based on WHO clinical staging of HIV disease in adults and adolescents. ${ }^{*} p<0.05$.

Regarding the basic components of food security, nearly half (48.6\%) of participants responded in the affirmative for the first primary question of the FSS instrument, that is, were they ever worried that their food would run out. Most of the participants had to eat the same food daily (Q3, 'yes' $=59.5 \%)$. Nearly half thought that the food they had was never enough (Q2,'yes' $=48 \%$ ).

A significant association with more food security was observed in the case of participants with $\geq 5$ years of schooling (AOR, 2.67; 95\% Cl, 1.20 to 5.95), higher SES, and males, considering the $P$ score (Table 1). Those aged $\geq 40$ years (AOR, 1.67; $95 \% \mathrm{Cl}, 0.74$ to 3.77), Hindus, members of joint families (AOR, $1.27 ; 95 \% \mathrm{Cl}, 0.61$ to 2.66 ), and those who were currently married were more likely to be food secure when considering $P$ score (Table 1). After controlling for predictors, the model explained between 26.4\% (Cox \& Snell R²) and 35.2\% (Nagelkerke $\mathrm{R}^{2}$ ) of the variance in food security; it correctly classified $72.8 \%$ of cases. The contribution of the independent variables was significant (Hosmer-Lemeshow test chi-square, 53.1; $p<0.01$ ).

Those participants currently in the early stages (1 or 2 ) of 
Table 3. Association of background variables with chronic food insecurity

\begin{tabular}{|c|c|c|c|c|}
\hline \multirow{2}{*}{ Variables } & \multicolumn{2}{|c|}{$\begin{array}{l}\text { Chronically food } \\
\text { insecure }\end{array}$} & \multirow{2}{*}{$\begin{array}{c}\text { Total } \\
(n=173)\end{array}$} & \multirow{2}{*}{$\begin{array}{c}\text { AOR }^{1} \\
(95 \% \mathrm{CI})\end{array}$} \\
\hline & No & Yes & & \\
\hline \multicolumn{5}{|l|}{ Age (y) } \\
\hline$<40$ & $62(54.4)$ & $52(45.6)$ & $114(65.9)$ & 1.00 (reference) \\
\hline$\geq 40$ & $36(61.0)$ & $23(39.0)$ & $59(34.1)$ & $1.37(0.61,3.08)$ \\
\hline \multicolumn{5}{|l|}{ Religion } \\
\hline Hindu & $87(58.4)$ & $62(41.6)$ & $149(86.1)$ & 1.00 (reference) \\
\hline Others ${ }^{2}$ & $11(45.8)$ & $13(54.2)$ & 24 (13.9) & $0.60(0.20,1.80)$ \\
\hline \multicolumn{5}{|l|}{ Sex } \\
\hline Male & $63(65.6)$ & $33(34.4)$ & $96(55.5)$ & 1.00 (reference) \\
\hline Female & $35(45.5)$ & $42(54.5)$ & $77(44.5)$ & $0.40(0.19,0.85)^{*}$ \\
\hline \multicolumn{5}{|l|}{ Marital status } \\
\hline Currently married & 70 (59.3) & $48(40.7)$ & $118(68.2)$ & 1.00 (reference) \\
\hline Others ${ }^{3}$ & $28(50.9)$ & $27(49.1)$ & 55 (31.8) & $0.92(0.41,2.05)$ \\
\hline \multicolumn{5}{|l|}{ Type of family } \\
\hline Nuclear & $49(54.4)$ & $41(45.6)$ & $90(52.0)$ & 1.00 (reference) \\
\hline Joint & $49(59.0)$ & $34(41.0)$ & $83(48.0)$ & $1.40(0.67,2.94)$ \\
\hline \multicolumn{5}{|l|}{ Education (y) } \\
\hline$<5$ & $23(37.1)$ & $39(62.9)$ & $62(35.8)$ & 1.00 (reference) \\
\hline$\geq 5$ & $75(67.6)$ & $36(32.4)$ & $111(64.2)$ & $2.84(1.30,6.22)^{*}$ \\
\hline \multicolumn{5}{|c|}{ Socioeconomic status } \\
\hline $\begin{array}{l}\text { Class I and II (PCI } \\
\geq \text { INR 3070/mo) }\end{array}$ & $55(82.1)$ & $12(17.9)$ & $67(38.7)$ & 1.00 (reference) \\
\hline $\begin{array}{l}\text { Class III, IV, and V } \\
\text { (PCI <INR } \\
3070 / \mathrm{mo})\end{array}$ & 43 (40.6) & $63(59.4)$ & $106(61.3)$ & $0.13(0.05,0.31)^{*}$ \\
\hline \multicolumn{5}{|c|}{ Total-to-earning-member ratio } \\
\hline$<4$ & 70 (59.3) & $48(40.7)$ & $118(68.2)$ & 1.00 (reference) \\
\hline$\geq 4$ & $28(50.9)$ & $27(49.1)$ & $55(31.8)$ & $1.76(0.78,3.98)$ \\
\hline Total & 98 (56.6) & 75 (43.4) & $173(100)$ & \\
\hline
\end{tabular}

Values are presented as frequency (\%).

$\mathrm{AOR}$, adjusted odds ratio; $\mathrm{Cl}$, confidence interval; $\mathrm{PCl}$, per capita income; INR, Indian rupees; Class I, Z INR 6140; Class II, INR 3070-6139; Class III, INR 1842-3069; Class IV, INR 921-1841; Class V, $\leq$ INR 920.

${ }^{1} \mathrm{AOR}$ was determined using binary logistic regression. For each independent variable, the AOR was calculated after adjusting for other independent variables.

${ }^{2}$ Other religions like Muslim, Christian, etc.

${ }^{3}$ Other marital status implies unmarried/divorced/separated.

${ }^{*} p<0.05$.

HIV/AIDS and those who were the only member of the family with the disease had significantly higher levels of food security (Table 2). However, participants with a duration of disease $<2$ years (AOR, 1.53; $95 \% \mathrm{Cl}, 0.78$ to 3.01 ) and initial presentation in the advanced stages ( 3 or 4 ) were more likely to be food secure than those with $\geq 2$ years' duration and earlier stages of presentation ( $A O R, 0.88 ; 95 \% \mathrm{Cl}, 0.44$ to 1.76 ), taking $\mathrm{P}$ score
Table 4. Association of disease-related variables with chronic food insecurity

\begin{tabular}{|c|c|c|c|c|}
\hline \multirow[t]{2}{*}{ Variables } & \multicolumn{2}{|c|}{$\begin{array}{l}\text { Chronically food } \\
\text { insecure }\end{array}$} & \multirow{2}{*}{$\begin{array}{c}\text { Total } \\
(n=173)\end{array}$} & \multirow{2}{*}{$\begin{array}{c}\text { AOR }^{1} \\
(95 \% \text { CI })\end{array}$} \\
\hline & No & Yes & & \\
\hline \multicolumn{5}{|c|}{ Duration of disease (y) } \\
\hline$\geq 2$ & $61(55.5)$ & $49(44.5)$ & $110(63.6)$ & 1.00 (reference) \\
\hline$<2$ & $37(58.7)$ & $26(41.3)$ & $63(36.4)$ & $1.54(0.77,3.09)$ \\
\hline \multicolumn{5}{|c|}{ Initial stage of disease ${ }^{2}$} \\
\hline Stage 3 and 4 & $32(58.2)$ & $23(41.8)$ & $55(31.8)$ & 1.00 (reference) \\
\hline Stage 1 and 2 & $66(55.9)$ & $52(44.1)$ & $118(68.2)$ & $0.74(0.36,1.51)$ \\
\hline \multicolumn{5}{|c|}{ Current stage of disease ${ }^{3}$} \\
\hline Stage 3 and 4 & $5(29.4)$ & $12(70.6)$ & $17(9.8)$ & 1.00 (reference) \\
\hline Stage 1 and 2 & $93(59.6)$ & $63(40.4)$ & $156(90.2)$ & $7.07(2.01,24.82)^{*}$ \\
\hline \multicolumn{5}{|c|}{ Presence of other family members suffering from HIV/AIDS } \\
\hline Yes & $59(51.8)$ & $55(48.2)$ & $114(65.9)$ & 1.00 (reference) \\
\hline No & $39(66.1)$ & $20(33.9)$ & $59(34.1)$ & $2.30(1.13,4.70)^{*}$ \\
\hline Total & $98(56.6)$ & $75(43.4)$ & $173(100)$ & \\
\hline
\end{tabular}

Values are presented as frequency (\%).

$\mathrm{AOR}$, adjusted odds ratio; $\mathrm{Cl}$, confidence interval; $\mathrm{ART}$, anti-retroviral therapy; WHO, World Health Organization; HIV, human immunodeficiency virus; AIDS, acquired immunodeficiency syndrome.

${ }^{1} \mathrm{AOR}$ was determined using binary logistic regression. For each independent variable, the AOR was calculated after adjusting for other independent variables.

${ }^{2}$ Initial stage of the disease at the time at the time of registration at the ART Centre based on WHO clinical staging of HIV disease in adults and adolescents.

${ }^{3}$ Stage of disease as recorded at the time of patient's last visit to the ART Centre based on WHO clinical staging of HIV disease in adults and adolescents.

${ }^{*} p<0.05$

into account (Table 2). The model explained between $6.2 \%$ $\left(\right.$ Cox \& Snell $R^{2}$ ) and $8.3 \%$ (Nagelkerke $R^{2}$ ) of the variance in food security; it correctly classified $60.7 \%$ of cases. The contribution of the independent variables was significant (HosmerLemeshow test chi-square, $11.1 ; p=0.03$ ).

Chronic food insecurity was significantly greater in case of females, $<5$ years schooling and belonging to lower SES (Table 3). The model here explained between $25.0 \%$ (Cox \& Snell $\mathrm{R}^{2}$ ) and $33.6 \%$ (Nagelkerke $\mathrm{R}^{2}$ ) of the variance of chronic food insecurity; it correctly classified $72.8 \%$ of cases (Hosmer-Lemeshow test chi-square, $49.8 ; p=0.00$ ).

When considering disease-related variables, it was found that the presence of other family members with HIV/AIDS and currently participant having advanced stages of the disease had a significant effect on chronic food insecurity (Table 4). The model here explained between $7.7 \%\left(C o x \&\right.$ Snell $\left.R^{2}\right)$ and $10.3 \%$ (Nagelkerke $R^{2}$ ) of the variance in chronic food insecuri- 
Table 5. Coping strategies adopted by study subjects $(n=173)$

\begin{tabular}{ll}
\hline $\begin{array}{l}\text { Coping strategies to deal with food insecurity in } \\
\text { acute phase of course of disease }\end{array}$ & Frequency (\%) \\
\hline Borrow money from any source & $97(56.1)$ \\
Borrow food or sell agricultural products & $21(12.1)$ \\
Support from children & $15(8.7)$ \\
Spousal support & $28(16.2)$ \\
Selling property & $14(8.1)$ \\
Previous savings, mortgaging/renting property & $10(5.8)$ \\
Loan from microfinance institution/bank/moneylender & $24(13.9)$ \\
\hline
\end{tabular}

${ }^{1}$ All are multiple responses.

ty, correctly classifying $62.4 \%$ of cases (Hosmer-Lemeshow test chi-square, $13.8 ; p=0.01$ ).

Various coping strategies were adopted by respondents during the course of the disease, particularly during the acute phase, to deal with food insecurity, as was noted from the responses to the open-ended question. Nearly half (56.1\%) of the respondents borrowed money from various sources, such as relatives, friends, neighbours, or employers. Some (13.9\%) borrowed money from money lenders, or took out loans from banks or from micro-financing institutions, such as Bandhan. Some of their spouses had to find new employment (16.2\%). In some cases (8.7\%), the children of participants were affected, not only by being sent to earn money but also by being taken out of school or sent to monasteries, known as ashrams, or to a relative's house. Participants also borrowed food from relatives or neighbours, or sold agricultural products in the case of those with farms (12.1\%), sold property (8.1\%), or used previous savings or mortgaged/rented property (5.8\%) (Table 5).

\section{DISCUSSION}

PLWHA constitute a special target group in a resource-poor setting like India, which is home to $25 \%$ of the world's hungry population [17]. The present study demonstrated $50.9 \%$ of households to be food secure and the remaining $49.1 \%$ to be food insecure. Food insecurity is highly prevalent, and varied, among PLWHA in both low- and high-resource contexts [1822]. A similar study conducted in 2008 in Aurangabad, India by van Elsland et al. [9] found food insecurity in $99.2 \%$ of participants among the households of PLWHA-much higher than the current findings-possibly because the study was conducted at the peak of a global food crisis. Heylen et al. [8] found one-fifth of PLWHA to be food insecure in South India. Studies in other countries [18-22] like Kenya, Canada, and the
US reported food insecurity in the range of $33.5 \%$ to $86.7 \%$. This variation might be due to different settings and/or due to different tools applied to determine food security.

The present study found a significant association of males with food security, implying that females are the more disadvantaged group with respect to food security. Sex differentiation has been a key issue in the context of HIV/AIDS and food security, as demonstrated in various studies. Studies by Heylen et al. [8] in Bengaluru (Bangalore), Weiser et al. [23], Normén et al. [19], Tsai et al. [24] and Bukusuba et al. [25] found females to be more food insecure. Females, being the primary caregivers in the home, may deprive themselves of their part of the meal to cope with a food shortage. Male respondents in the present study might not be aware of the actual scenario in the household kitchen. Previous studies in India demonstrated female PLWHA to have poorer quality of life $[26,27]$.

The present study found higher SES and education to be significantly associated with food security. This is supported by various studies among PLWHA and other populations in India $[28,29]$ and elsewhere $[19,21,30]$. We used a modified BG Prasad classification of SES, where $\mathrm{PCl}$ is taken into account. Having higher $\mathrm{PCl} /$ monthly family income led to increased purchasing power for food. Moreover, a higher level of educational qualification increases the chance of higher income, and thus, food security.

Older age was found to be associated with household food security in this study, though not significantly associated. A study by Anema et al. [31] found younger age to be associated with household food insecurity. Older persons are usually dependent members of the family. In contrast, the household is often plunged into financial crisis when the younger population that constitutes the bulk of the earning members in the household falls sick. Moreover, the younger age group is more sexually active, and thus more prone to contract HIV than older persons.

Family background has always been an important determinant in traditional settings in India. Belonging to a joint family or being currently married was associated with a greater likelihood of food security. Quite naturally, food and financial aid is more readily available when one belongs to a joint family. This was also supported by the responses of nearly half of participants that they borrowed money from anyone, including family members. Spousal backing was also sought by a substantial percentage (16.2\%).

Those participants currently in the early stages of the dis- 
ease were found to be significantly more food secure. Previous studies have found associations between food security and immunological status. In British Columbia [19] and San Francisco [21], food-insecure individuals had significantly lower CD4 counts at ART initiation compared to others. CD4 count could be taken as proxy measure of disease stage, that is, lower CD4 count implies a more advanced stage of the disease. Since these studies were cross-sectional, the direction of causality is not known. Studies from the pre-ART era show strong associations between malnutrition and immunological decline $[32,33]$, but did not focus specifically on food security.

Interestingly, the present study showed no association between the initial stages of the disease and food security; rather, earlier initial stages were associated with a lower likelihood of food security. This might be due to chance or because questions were asked only about the past year. Additional research is needed to clarify the impact of the stage of the disease on food insecurity.

Households with only one diseased person were significantly more food secure than those with other diseased members. Multiple people with HIV/AIDS in a household leads to additional costs related to medical care and more missed days of work due to illness leads to food insecurity.

HIV/AIDS poses a direct threat to household food security. When a person is sick, the household not only has to manage without their labour input, but also with loss of labour from caregivers [34]. There is increased spending on healthcare, decreased productivity, and higher demands for care, all of which can impact food security. Repeated spells of illness only accelerate the households' struggles.

Respondents in the present study showed a wide variety of coping mechanisms, from seeking support from relatives or help from social connections to selling productive assets. Frequently, children were forced to discontinue schooling or were sent to other places because families could not bear their expenses. A similar situation was observed in studies by Parker et al. [6]. Other findings, like the migration of women in search of jobs and support from children, corroborated the observations of other authors $[25,35,36]$. However, even though relatives were often willing to provide some support for children in their extended families, responsibility for the support of children often exceeds their capacity. Despite many NGOs now operating in this community, support is restricted and need is growing.

This study is the first of its kind to be conducted in a high- prevalence district [10] in West Bengal. The household setting of the study was selected to reduce the possibility of a socialdesirability bias. However, due to the nature and sensitivity of this issue, the respondents might have been hesitant to answer all the questions properly. This problem was anticipated and addressed by asking open-ended questions that complemented the data from structured questionnaires.

In summary, although nearly half of the households of PLWHA were food secure, females, poorer participants, and those in the advanced stages of the disease were more food insecure. Distinct measures in addition to routine preventive and treatment options like special food subsidies, incomegenerating schemes, and vocational training programs oriented specifically toward women will help PLWHA to lead a dignified life. These are necessary both for the acute crisis period of the disease and for sustaining PLWHA over the long term. Further research is needed to decipher the wider picture in the Indian context.

\section{ACKNOWLEDGEMENTS}

This study was conducted with help of ART Centre, North Bengal Medical College \& Hospital and NGOs working for PLWHA, Ekta-Vihaan and Sanghabaddho. The study was awarded the Pyarelal Sharma memorial award at the National Conference organised by the Indian Association of Preventive and Social Medicine (IAPSMCON), held in 2016 in Gandhinagar, Gujarat, India.

\section{CONFLICT OF INTEREST}

The authors have no conflicts of interest associated with the material presented in this paper.

\section{ORCID}

Pallabi Dasgupta http://orcid.org/0000-0002-6721-2353

Sharmistha Bhattacherjee http://orcid.org/0000-0001-80819195

Dilip Kumar Das http://orcid.org/0000-0002-3027-0728

\section{REFERENCES}

1. Food and Agriculture Organization of the United Nations. World foods summit: Rome declaration on world food securi- 
ty [cited $2016 \mathrm{Jul}$ 28]. Available from: http://www.fao.org/docrep/003/w3613e/w3613e00.HTM.

2. World Health Organization. HIV/AIDS: data and statistics [cited 2016 Jul 28]. Available from: http://www.who.int/hiv/data/ en/.

3. Food and Agriculture Organization of the United Nations. HIV/AIDS, food security and nutrition [cited 2016 feb 23]. Available from: http://www.fao.org/ag/agn/nutrition/household_hivaids_en.stm.

4. International Labour Office. Action against HIV/AIDS in Africa: an initiative in the context of the world of work. Geneva: International Labour Office 1999; p. 2-8.

5. Masuku MB, Sithole MM. The impact of HIV/AIDS on food security and household vulnerability in Swaziland. Agrekon 2009;48(2):200-222.

6. Parker DC, Jacobsen KH, Komwa MK. A qualitative study of the impact of HIV/AIDS on agricultural households in Southeastern Uganda. Int J Environ Res Public Health 2009;6(8): 2113-2138.

7. Alemu A, Bezabih T. The impacts of HIV/AIDS on livelihoods and food security in rural Ethiopia: results from household survey in four regions; 2008 [cited 2016 Feb 23]. Available from: http://documents.wfp.org/stellent/groups/public/documents/ena/wfp221565.pdf.

8. Heylen E, Panicker ST, Chandy S, Steward WT, Ekstrand ML. Food insecurity and its relation to psychological well-being among South Indian people living with HIV. AIDS Behav 2015;19(8):1548-1558.

9. van Elsland SL, van der Hoeven M, Joshi S, Doak CM, Ponce MC. Pressure cooker ownership and food security in Aurangabad, India. Public Health Nutr 2012;15(5):818-826.

10. Department of AIDS Control, Ministry of Health \& Family Welfare, Government of India. State fact sheets; 2014 [cited 2016 Feb 23]. Available from: http://naco.gov.in/upload/2014\%20 mslns/State\%20Fact\%20Sheet\%202013-14.pdf.

11. Office of the Registrar General and Census Commissioner, India. Primary census abstract; 2011 [cited 2016 Feb 23]. Available from: http://www.censusindia.gov.in/2011census/hlo/ pca/pca_data.html.

12. Lwanga LK, Lemeshow S; World Health Organization. Sample size determination in health studies: a practical manual; 1991 [cited 2016 Feb 23]. Available from: http://apps.who.int/iris/ handle/10665/40062.

13. Freedom from Hunger. Measuring food security at Freedom from Hunger [cited $2016 \mathrm{Feb} 23$ ]. Available from: http://www.
seepnetwork.org/filebin/pdf/step_up/53803861-FFH-FoodSecurity-description.pdf.

14. Mangal A, Kumar V, Panesar S, Talwar R, Raut D, Singh S. Updated BG Prasad socioeconomic classification, 2014: a commentary. Indian J Public Health 2015;59(1):42-44.

15. Sharma R. Revision of Prasad's social classification and provision of an online tool for real-time updating. South Asian J Cancer 2013;2(3):157.

16. World Health Organization. Antiretroviral therapy for HIV infection in adults and adolescents: recommendations for a public health approach. Geneva: World Health Organization; 2010, p. 73-80.

17. Dev SM, Sharma AN. Food security in India: performance, challenges and policies; 2010 [cited 2016 Feb 23]. Available from: http://re.indiaenvironmentportal.org.in/files/food $\% 20$ security\%20in\%20india.pdf.

18. Mamlin J, Kimaiyo S, Lewis S, Tadayo H, Jerop FK, Gichunge C, et al. Integrating nutrition support for food-insecure patients and their dependents into an HIV care and treatment program in Western Kenya. Am J Public Health 2009;99(2):215221.

19. Normén L, Chan K, Braitstein P, Anema A, Bondy G, Montaner $J S$, et al. Food insecurity and hunger are prevalent among HIV-positive individuals in British Columbia, Canada. J Nutr 2005;135(4):820-825.

20. Mtika MM. The AIDS epidemic in Malawi and its threat to household food security. Hum Organ 2001;60(2):178-188.

21. Weiser SD, Bangsberg DR, Kegeles S, Ragland K, Kushel MB, Frongillo EA. Food insecurity among homeless and marginally housed individuals living with HIV/AIDS in San Francisco. AIDS Behav 2009;13(5):841-848.

22. Muiruri, Wangui MG. Effects of HIV/AIDS on household food security: a study conducted in Mukuyu Division, Murang'a South District, Kenya [cited 2016 Feb 23]. Available from: http://ir-library.ku.ac.ke/handle/123456789/7274.

23. Weiser SD, Leiter K, Bangsberg DR, Butler LM, Percy-de Korte F, Hlanze $Z$, et al. Food insufficiency is associated with high-risk sexual behavior among women in Botswana and Swaziland. PLoS Med 2007;4(10):1589-1597.

24. Tsai AC, Bangsberg DR, Emenyonu N, Senkungu JK, Martin JN, Weiser SD. The social context of food insecurity among persons living with HIV/AIDS in rural Uganda. Soc Sci Med 2011; 73(12):1717-1724.

25. Bukusuba J, Kikafunda JK, Whitehead RG. Food security status in households of people living with HIV/AIDS (PLWHA) in a 
Ugandan urban setting. Br J Nutr 2007;98(1):211-217.

26. Vigneshwaran E, Padmanabhareddy $Y$, Devanna N, AlvarezUria G. Gender differences in health related quality of life of people living with HIV/AIDS in the era of highly active antiretroviral therapy. N Am J Med Sci 2013;5(2):102-107.

27. Mahalakshmy T, Premarajan K, Hamide A. Quality of life and its determinants in people living with human immunodeficiency virus infection in puducherry, India. Indian J Community Med 2011;36(3):203-207.

28. Agarwal S, Sethi V, Gupta P, Jha M, Agnihotri A, Nord M. experiential household food insecurity in an urban underserved slum of North India. Food Sec 2009;1(3):239-250.

29. Nnakwe N, Yegammia C. Prevalence of food insecurity among households with children in Coimbatore, India. Nutr Res 2002; 22(9):1009-1016.

30. Furness BW, Simon PA, Wold CM, Asarian-Anderson J. Prevalence and predictors of food insecurity among low-income households in Los Angeles County. Public Health Nutr 2004; 7(6):791-794.

31. Anema A, Weiser SD, Fernandes KA, Ding E, Brandson EK, Palmer $A$, et al. High prevalence of food insecurity among HIV-infected individuals receiving HAART in a resource-rich setting. AIDS Care 2011;23(2):221-230.
32. Mocroft A, Kirk O, Barton SE, Dietrich M, Proenca R, Colebunders $\mathrm{R}$, et al. Anaemia is an independent predictive marker for clinical prognosis in HIV-infected patients from across Europe. EuroSIDA study group. AIDS 1999;13(8):943-950.

33. Paton NI, Sangeetha S, Earnest A, Bellamy R. The impact of malnutrition on survival and the CD4 count response in HIVinfected patients starting antiretroviral therapy. HIV Med 2006;7(5):323-330.

34. Piot $P$, Andersen P. AIDS: the new challenge to food security. Washington, DC: International Food Policy Research Institute; 2002, p. 5-6.

35. Coon K, Ogden J, Odolon J, Obudi-Owor A, Otim C, Byakigga J, et al. Transcending boundaries to improve the food security of HIV-affected households in rural Uganda: a case study; 2007 [cited 2016 Jul 17]. Available from: http://www.icrw.org/ sites/default/files/publications/Transcending-Boundaries-toImprove-the-Food-Security-of-HIV-affected-Households-inRural-Uganda-A-Case-Study.pdf.

36. Gillespie S, Kadiyala S. HIV/AIDS food and nutrition security: from evidence to action; 2005 [cited 2016 Jul 17]. Available from: file://C:/Users/user/Downloads/hiv_aids_and_food_ and_nutrition_security.pdf. and Nutrition Security. 